\section{En upraktisk håndbok}

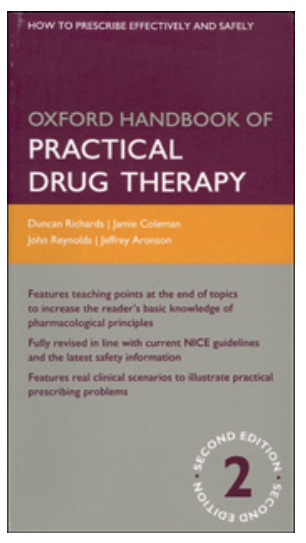

Duncan Richards, Jeffrey Aronson,

John Reynolds et al.

Oxford handbook of practical drug therapy

2. utg. 795 s, tab, ill. Oxford: Oxford University

Press, 2011. Pris GBP 28

ISBN 978-0-19-956285-5

Denne håndboken i lommeformat er en av mange i serien Oxford handbook of .... Den er myntet på medisinstudenter, leger i spesialisering, allmennpraktikere, farmasøyter og sykepleiere.

Boken er inndelt i 15 terapikapitler, f.eks. Nevrologiske sykdommer, hvert av disse med mange små underkapitler om de ulike anvendte legemidlene, på gruppenivå og enkeltvis. Her finnes nøkkelinformasjon om bl.a. indikasjoner, interaksjoner og bivirkninger, og en enkel figur viser legemidlenes virkningsmekanisme. Nytt $i$ andre utgave er spredte tekstrammer med såkalte «teaching points», noe som er ment å øke leserens kunnskap om farmakologiske prinsipper.

Når all medikamentell behandling skal skjæres ned til å passe i frakkelommen, blir alt nødvendigvis veldig kortfattet. Noen steder har man vært i overkant hard med kniven, f.eks. er ikke antidepressivet mirtazapin nevnt, andre steder generaliserer man så kraftig at resultatet blir usant, f.eks. hevder man at samtlige selektive serotoninreopptakshemmere primært metaboliseres av CYP2D6.

Figurene blir også en salderingspost. For en rekke nevro- og psykofarmaka har man kun funnet plass til å tegne en liten hjerne. Når man generaliserer så brutalt, ender man til slutt med ikke å si noe som helst. En figur som viser at selektive serotoninreopptakshemmere virker på hjernen, kan man etter min mening like gjerne utelate.

Et annet problem er av mer generell karakter: Kan man i det hele tatt bruke en britisk forskrivningshåndbok som kart i et norsk terreng? De to landene har ulikt repertoar av markedsførte legemidler (f.eks. benzodiazepiner), ulike terapianbefalinger (f.eks. ved infeksjoner), og ulike forskrivningsregler.

Denne boken er sikkert utmerket for britiske leger, men jeg kan egentlig ikke se at den fortjener noen plass i norske frakkelommer, bokhyller eller lesesaler. Norsk legemiddelhåndbok og Felleskatalogen - begge lett tilgjengelige på norsk og på nett - dekker det meste denne boken tilbyr, og gir i tillegg praktisk nyttig informasjon om f.eks. tablettstyrker, priser og refusjonskoder. Trenger man mer dyptgående legemiddelinformasjon, er mange gode nettsider, som www.interaksjoner.no, UpToDate, Helsebiblioteket, regionale legemiddelinformasjonssentre (RELIS) og Norsk elektronisk legehåndbok (NEL), bare noen få tastetrykk unna, også for en travel kliniker. Denne boken tilfredsstiller et behov vi ikke har.

\section{Andreas Austgulen Westin}

Avdeling for klinisk farmakologi

St. Olavs hospital

\section{Rimelig god lærebok om hjertesvikt}

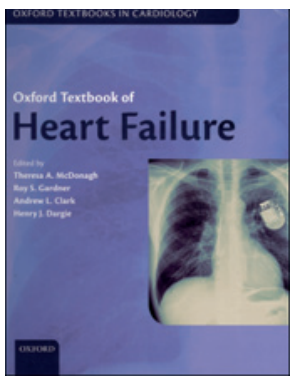

\author{
Theresa A. McDonagh, Roy S. Gardner,
}

Andrew L. Clark et al, red.

Oxford textbook of heart failure

641 s, tab, ill. Oxford: Oxford University Press, 2011. Pris GBP 110

ISBN 978-0-19-957772-9

Hjertesvikt er en progredierende og alvorlig tilstand med en prognose tilsvarende alvorlig kreftsykdom, og dessverre med økende prevalens. Til tross for en betydelig mengde bøker om hjertesvikt har forfatterne lyktes å markere seg med denne første utgaven. Sammenliknet med Braunwald, Topol og andre tunge oppslagsverk er nok denne utgivelsen en litt lettere variant, men det faglige innholdet er av gjennomgående god kvalitet. Inndelingen kan delvis virke litt vilkårlig: Av 18 hoveddeler omhandler tre henholdsvis etiologi, molekylær patofysiologi og patofysiologi, og står alene for en tredel av sidetallet. Det er en del innholdsmessig overlapp i disse, men den gode didaktiske oppbyggingen og forfatterrelatert forskjellig vinkling gjør det likevel verdt å lese dem hver for seg. På den andre siden er enkelte vesentlige forhold litt snevert omtalt. Jeg savner f.eks. bedre belysning av det sympatoadrenerge systemet ved hjertesvikt - nedregulering av betareseptorer er for så vidt nevnt, mens underliggende mekanismer eller betydning for progrediering av hjertesvikt mangler. Kardiomyopatiene kunne stått som eget kapittel, de er litt vilkårlig organisert under genetikk. Omtalen er imidlertid grundig, med en inndeling som følger siste klassifikasjon fra European Society of Cardiology.

Kapitlet om medikamentell behandling er glimrende og selv for erfarne behandlere absolutt verdt å studere i detalj, skrevet av forfattere som står bak mange av de mest sentrale medikamentstudiene. Det finnes dessverre fortsatt kun få medikamentgrupper som reduserer morbiditet og mortalitet ved hjertesvikt. Effekten av medikamentene kan imidlertid variere stort fra pasient til pasient, bl.a. på bakgrunn av genetiske faktorer, som polymorfismer i pasientens betaadrenerge reseptorer eller angiotensinkonverterende enzym, eller interaksjoner med andre medikamenter. Selv om dette i hverdagen som regel ikke byr på større problemer, kunne farmakogenomikk og farmakogenetikk ved hjertesvikt vært nevnt og ville ha gjort boken enda mer fremtidsrettet. Teksten om kirurgisk behandling av hjertesvikt, inkludert «kunstig hjerte» og transplantasjon, er velskrevet. Siden konvensjonell mitralklaffekirurgi ved lekkasje er omtalt som eget underpunkt, virker det litt underlig at ikke også transkateter aortaventilimplantasjon ved aortastenose er tatt med her.

Ikke-medikamentelle tiltak er viet god plass, og prinsipper ved terminal hjertesvikt og palliasjon er omtalt. I tråd med vektleggingen av kronisk hjertesvikt er akutt hjertesvikt viet mindre plass. Utgiverne retter avslutningsvis blikket mot fremtiden og omtaler mer eller mindre håpefulle kandidater for morgendagens hjertesviktbehandling. De fleste litteraturkildene er nye og representative.

Innbindingen er solid, papirkvaliteten god, og den utstrakte bruken av illustrasjoner, figurer og bilder, sammen med god skriftstørrelse, gjør boken lettlest. Samlet sett er min konklusjon at boken er solid og oppdatert, skrevet av anerkjente eksperter hovedsakelig fra engelske universitetssykehus, og synes å være svært relevant for norske forhold.

Jeg anbefaler den som lærebok til alle som arbeider med hjertesvikt, først og fremst kardiologer, indremedisinere, nefrologer, geriatere, hjertekirurger og allmennpraktikere, samt spesialsykepleiere ved for eksempel hjertesviktpoliklinikker.

Thomas von Lueder

Kardiologisk avdeling

Akershus universitetssykehus 